\title{
Pengembangan Bahan Ajar Media Pembelajaran Matematika Dan Teknologi Informasi Komunikasi
}

\author{
Buyung $^{1 *}$, Zulyadaini ${ }^{2}$ \\ ${ }^{1}$ Fakultas Keguruan Ilmu Pendidikan (FKIP) Univeristas Bengkulu \\ ${ }^{2}$ Fakultas Keguruan Ilmu Pendidikan (FKIP) Univeristas Batanghari Jambi \\ *Correspondence email: buyung@unib.ac.id, zulyadaini.unbari@gmail.com
}

\begin{abstract}
There are no teaching materials used in learning media and information communication technology specifically for mathematics. The existing material is still general in nature so it is difficult for students to apply it to making mathematics-related media. Therefore, it is necessary to develop teaching materials for mathematics learning media and information communication technology that are specifically related to mathematics. In the implementation of research using research and development methods using the instructional development model (MPI). The subjects were FKIP even semester students. In collecting data using observation, interviews and questionnaires. Data analysis used descriptive qualitative. The results of the study obtained feasibility in terms of design validation with $89 \%$ feasibility, expert validation with $90 \%$ feasibility and material expert validation obtained $90.76 \%$ feasibility. In addition, the results of the one to one learner obtained a feasibility result of $93.3 \%$. Followed by a small group trial obtaining a feasibility of $92 . \%$. Then in the field trial, it obtained a feasibility of $91.6 \%$. Based on these results, it is concluded that teaching materials are suitable for use in learning.
\end{abstract}

Keywords: instructional development model (MPI); teaching materials;, mathematics learning media and information communication technology

\section{PENDAHULUAN}

Perkembanganan pada segi IPTEK selalu berkembangan yanga mengikuti zamannya sehingga yang menuntut manusia harus dapat mengikuti permbangannya dengan cara mengupadate informasiinfaromasi tentang ilmu dan teknolgi yang berkembangan tersebut, termasuk pada dunia pendidikan. Perkembangan yang terjadi pada dunia pendidikan juga mengalami perubahan secara signifikan mulai dari ilmu pengahuan, proses mengajar, media pembelajaran dan yang lainnya. Untuk mengikuti perkembangan tersebut, maka harus dipersiapkan tenaga pendidik yang memiliki kompentesi dan siap bersaing ketika di tempat kerjanya. Oleh sebab itu, Sebagai calon pendidik atau calon guru, maka perlu melihat secara komprehensif tentang kebutuhan pendidik atau guru dalam proses pembelajaran dikelas sehingga pembelajaran lebih optimal ketika di realisasinya.

Matematika merupa salah satu bidang ilmu yang banyak kurang disukai oleh siswa, karena materinya banyak dalam bentuk abstrak sehingga siswa sulit untuk memahaminya. Permasalaha yang terjadi tersebut harus segara di atas di cari solusi keluarganya salah satu media pembelajaran. Menyikapi media pembelajaran yang menjadi salah satu solusi, maka perlu media yang dibuat atau digunakan sesuai dengan kebutuhan dan materi yang akan dipelajari, serta perkembangan zaman. Tutuntan ini menuntut guru harus dapat menndesain media pembelajaran yang sesuai, sehingga dibutuh kompetesi dalam mendesaian, mengembangakan, menggunakan, memanfaatkan media pembelajaran yang sesuai baik segi materi, maupunkarakteristik peserta didik. Hal tersebut akan dapat dimiliki oleh pendidik atau guru ketika mendapatkan pembekalan yang jelas saat menimba ilmu di perkuliahan seperti pada mata kuliah media pembelajaran matematika dan teknologi informasi komunikasi.

Namun yang terjadi, bahan ajar khusus pada media pembelajaran matematika dan TIK belum ada. Materi yang dipelajari merupaka materi media secara umum dan belum mengaitkan dengan materi matematika. Hal tersebut membuat mahasiswa kesulitan ketika membuat media pada materi matematika yang banyak bersifat abstrak. Hal tersebut bisa berakibat pembelajaran kurang efektif dalam terutama dari sumber-sumber belajar yang digunakan.

Fakta di lapangan yang ditemukan di atas harus dicari solusi pemecahan masalahnya salah satu solusinya adalah membuat bahan ajar yang sesuai dengan kebutuhan mahasiswa. Supaya bahan ajar di buat secara ilmiah makan dilakukanlah penelitian dan pengembangan bahan Ajar. Pada penelitian perlu dikaji secara menyuruh bagaimana proses penggunaan bahan pada pelaksanaan pembelajaran? Kemudian bagaimanakah prosedur pengembangan bahan ajar Media Pembelajaran matematika dan teknologi informasi komunikasii?

Terkait dengan elemen yang akan di cari, maka perlu dikaji secara komprehensif tentang teori pengembangan, bahan ajar, media pembelajaran dan teknologi komunikasi, serta model pengembangan istuksional.

\section{Konsep Pengembangan}

Menurut Atwi Suparman (2011) menjelasakan bahwa pengembangan pembelajaran merupakan suatu 
proses yang sistematis dalam mengidentifikasi masalah, mengembangkan bahan dan strategi instuksional, serta mengevaluasi efektif dan efisien dalam mencapai tujuan instruksional. Richey and Klein (2007) Menginstruksikan bahwa sistematika desain, pada proses pengembangan dan evaluasi harus bersumberkan data empiris dengan tujuan memciptakan produk pembelajaran dan bukan produk pembelajaran, model-model baru atau menyempurnakan pengembangan produk yang ada.
Kemudian (Buyung, 2018) menyebutkan bahwa Pengembangan instuksional adalah suatu proses sistematis dengan tahapan mendesaian, mengembangkan, mengevaluasi dan menghasilkan suatu produk, maupun alat atau model instuksional terbaru atau perbaikan dari yang sebelumnya.

\section{Model Pengembangan Instruksional (MPI)}

Struktur model pengembangan pada gambar 1 (Atwi Suparman, 2010)

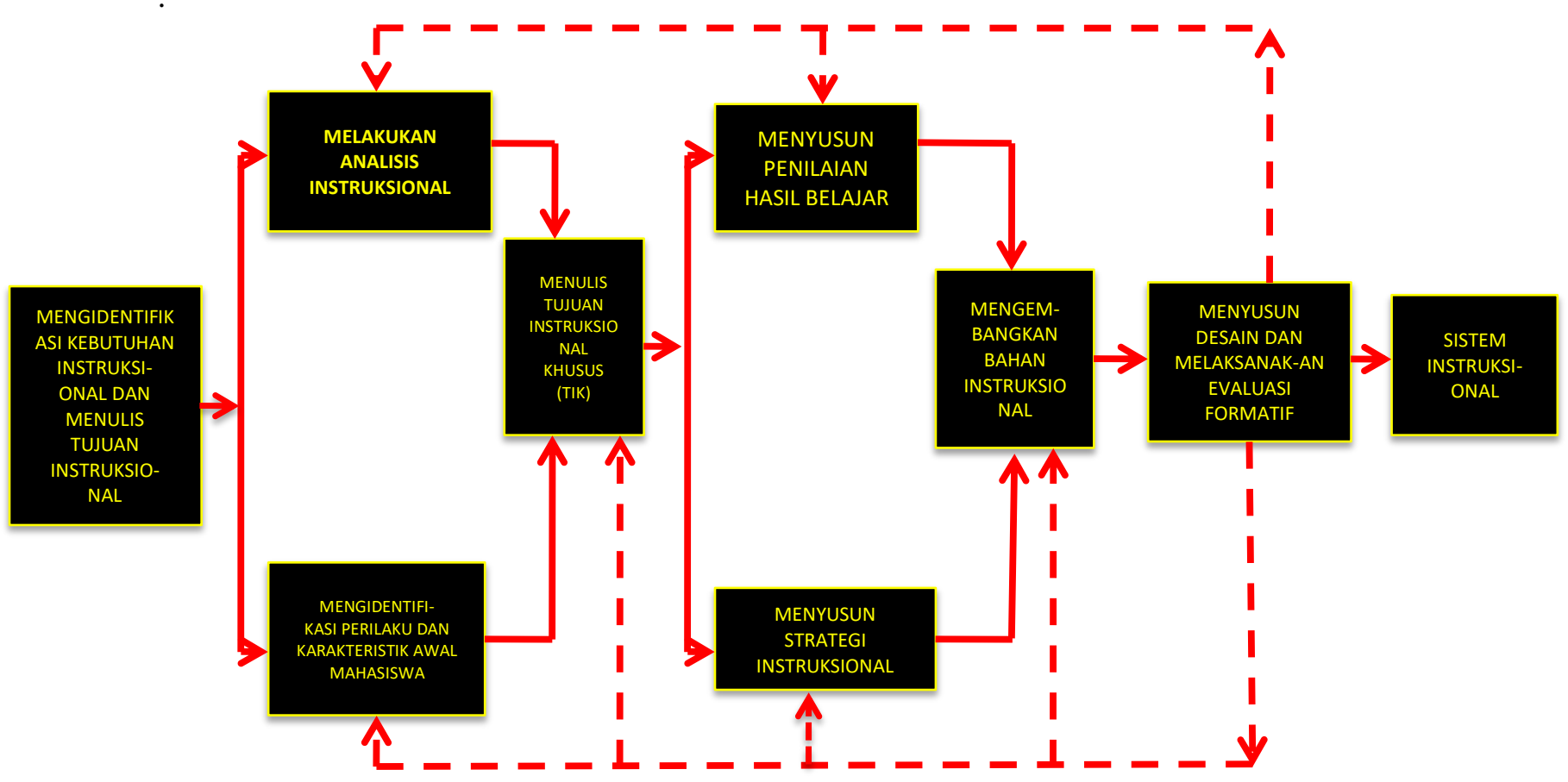

Gambar 1. Langkah Model Pengembangan instruksional (MPI)

1. Identifikasi kebutuhan instuksional dan menulis tujuan instuksional. Pada indentifikasi akan mengkaji kesejangan antra harapan dengan keadaan yang terjadi sebenarnya. Kemudian dilanjutkan dengan pencari pemecahan masalah. Pada proses ini yang menjadi sumber informasi ialah peserta didik/lulusan, masyarakat (yang menggunakan lulusan), dan pendidik. Kemudian pada tahapan kedua yaitu menulis tujuan instruksional umum.

2. Melakukan analisis Instruksional. Menurut Atwi suparman (2012) Analysis Instruksional merupakan suatu proses untuk menjabarak komptentensi umum menjadi beberapa komptensi khusus yang tersusun inci. Susunan untuk gambaran perilaku dari subkompotensi dapat disusun secara hirarki, prosedural, pengelompokan maupun kombinasi. Penentuan struktur tergantung pada subkompetensi yang ditentukan.

3. Identifikasi perilaku dan karakteristik awal peserta didik. Pada Perilaku pertama sekali perlu dilihat siapa kelompok sasaran, populasi sasaran, jenjang pendidikan, kemampuan dan ketrampilan yang sudah dikuasai peserta didik. Kemudian kedua ialah Karakteristik awal peserta didik, Karakteristik awal seperti minat, motivasi, kebiasan belajar mandiri, akses terhadap saluran komunikasi, kemampuan belajar dan berpikir, domisili atau tempat tinggal

4. Menulis tujuan instruksional khusus. Tahapan ini merupakan penentuan tujuan spesifik dan pembelajaran. Untuk mencapai tujuan umum yang ditetapkan maka perlu merinci tujuan-tujuan khusus yang harus dikuasai peserta.

5. Menyusun instrument penilaian hasil belajar. Dalam penyususan instrumen hasil belajar harus memperhatikan setiap kompetensi khusus yang sudah di tetapkan, sehingga terukur penilainya.

6. Menyusun strategi instruksional. Pada menyusun startaegi sudah di susun berdasar tuntuna yang ada pada silbaus dan RPS..

7. Mengembangkan bahan instruksional. Dalam Mengembangkan bahan instrukisonal perlu melihat institusi atau organisasi penyelenggara, bentuk pendekatan kegiatan intruksional biasa dalam mandiri, tatap muka, atau pembelajaran kombinasi atau blended learning.

8. Menyusun desain dan melaksanakan evaluasi formatif. Dapal penyusun desain melakuakn rancangan instrumen dan melakukan evaluasi 
formatif sebagai masukan untuk perbaikan atau revisi

9. Sistem instruksional. Hasil dari evalusi formatif di atas adalah system intruksional yang telah siap untuk diimplimentasikan.

10.Implemntasi, Evalusi sumatif dan difusi inovasi. Kegiatan ini terdiri dari: a) Impelentasi yang dilakukan pada uji coba lapangan namun dalam skala yang lebih luas b) Evaluasi sumatif adalah proses menilai objek, dalam hal ini adalam system intruksional, hasil proses desain intruksional. c) Melakukan difus inovasi.

\section{Relevansi Model Pengembangan}

Penggunaan model pengembangan istuksional (MPI) di anggap relevansi dengan pengembangan bahan ajar karena pada Model Pengembangan Instruksional (MPI) memiliki alur yang rinci, susunan tujuan instruksional secara hirarki, ada analis indentifikasi masalah dan pemecahannya, kemudian ada pelaksanaan validasi dan uji coba unutk melihat kelayakkan model. Selain itu pada setiap tahapan-tahapan memberikan informasi untuk keperluan praktis dan bisa melakukan revisi-revisi produk.

\section{Bahan ajar}

Hamdani (2011) menjelaskan bahwa pada bahan ajar terdiri dari pengetahuan, sikap serta keterampilan yang akan dibelajarkan oleh siswa untuk mencapai kompetesi yang sudah ditetapkan. Bahan ajar adalah seperangkat materi/substansi pembelajaran (teaching material) yang disusun secara sistematis, menampilkan sosok utuh dari kompetensi yang akan dikuasai siswa dalam kegiatan pembelajaran (Depdiknas, 2008). Dengan demikian, bahan ajar merupakan materi-materi yang disusun secara sistematis yang bermuatan pada aspek pengetahuan, keterampilan, serta sikap yang harus di miliki oleh peserta didik setelah melakukan pembelajaran.

Rowntree dalam Awalludin menggolongkan bahwa ajar menjadi:1) Buku, pamplet, bahan cetak yang ditulis dan dikembangkan. 2) Pedoman belajar peserta didik. 3) Bahan belajar secara pada program pendidikan untuk jarak jauh. 4) Buku kerja guru seperti program-program audio, program video dan komputer. 5) Pedoman pratikum.

\section{Media pembelajaran dan Teknologi informasi komunikasi}

Media berasal dari bahasa latin, yang berati "medium" yang artinya "perantara, tengah ataupun pengantar". Menurut Bovee dalam Asyhar (2012), media berfungsi sebagai pengantar atau perantara antara pesan dari pengirim (sender) dengan penerima (receiver) pesan). Kemudian pembelajaran berasa dari bahasal inggris "instruction" yang berarti proses pembelajaran atau interaktif antara guru dengan peserta didik siswa secara dinamis. Berdasarkan kedua kata tersebut maka media pembelajaran bisa diartikan semua hal yang digunakan sebagai media dalam proses pembelajaran (Asyhar, 2012).

Arsyad (2014) media dapat dikelompokkan menjadi (1) Media berbasis manusia (seperti guru, instruktur, dan lain-lain); (2) Media cetak (3) Media visual (4) Media audio-visual dan (5) Media yang menggunakan komputer .

Kemudian Information and Communication Technology (ICT) merupakan teknologi yang mengunakan perangkat elektronik, komputer dan telekomunikasi dan di dalamnya tercakup perangkat lunak, serta dapat digunakan untuk membuat, menyimpan, mengirimkan, menerjemahkan, dan memanipulasi informasi dalam berbagai bentuk. Teknologi komunikasi seperti Internet, Radio, Intranet, dan sebagainya. Berdasarkan teori tersebut maka Teknologi Informasi dan Komunikasi (TIK) adalah segala kegiatan yang terkait dengan pemrosesan, pengelolaan dan penyampaian atau pemindahan informasi antar sarana / media. (https://bpptik.kominfo.go.id/glosarium/teknologiinformasi-dan-komunikasi/ (diakses 9 Februari 2020).

Bahan ajar media pembelajaran matematikan dan teknologi yang dimaksud adalah bahan ajar dalam bentuk cetak yang berisikan tentang materi media pembelajaran matematika baik dalam bentuk alat peraga yang besifat konvensioanl maupun yang bersifat berbasis pada teknologi informasi komunikasi.

\section{METODE}

Pelaksanaan pelenelitian menggunak metode reasearh dan development $(\mathrm{R} \& \mathrm{D})$.. Waktu pelaksanaan dilakukan pada semester genap, dengan subjek penelitian adalah mahasiswa pendidikan matematika. Prosedur penelitian dan pengembangkan ini dimulai dari penelitian pendahaluan, perencanaan pengembangan, pelaksanaaan pengembangan. Pengumpulan data menggunakan observasi, wawancara, dan angket. Kemudian di validasi oleh ahli atau one to one expert, yaitu ahli desain, ahli media, dan ahli materi, kemudian dilakukan evalusi evaluasi satu-satu untuk desain, mengidentifikasi kesalahan-kesalahan nyata, keterbacaan terhadap kesulitan dalam memahami isi atau materi bahan ajar, dilanjutkan lagi evaluasi kelompok kecil untuk mendapatkan Informasi tentang kemudahan dalam memahami materi, kemenarikan kegiatan intruksional, sitematis kegiatan intruksional, dan butir tes. Setelah itu dilakukan uji coba lapangan yang bertujuan mendapatkan informasi kekurang produk ketika dipakai pada keadaan sama dengan keadaaan pada waktu produk dipakai pada populasi sasaran nanti. Analisis data menggunakan analisis deskriprif 


\section{HASIL DAN PEMBAHASAN}

\section{Penelitian pendahuluan}

Hasil observasi pada penelitian pedahuluan ditemukan bahwa bahan ajar media pembelajaran matematika masih mengambil sumber yang bersifat umum dan belum ada bahan ajar yang khusus untuk media pembelajaran matematika dan teknologi informasi komunikasi. Selian itu hasil wawancara dengan mahasiswa, menunjukkan bahwa materi yang diberikan masih bersifat umum yang mengakibatkan teori yang dipelajari ketika di praktikan pada materi matematika mengalami perbedaan karena media matematika membutuhkan media yang khusus untuk menjelaskan materi yang dipelajari, hal tersebut membuat mahasiswa mendapatkan kesulitan. Sehingga untuk membuat media yang sesuai, mahasiswa harus kerja keras dalam mendesain dan membuat atau memproduksi media pembelajaran matematika dan TIK. Selain itu wawancara dengan dosen yang mengajar menggambarkan sulit mencari referensi buku yang sesuai dengan media pembelajaran matematika dan TIK yang mencakup secara utuh dalam satu bahan ajar yang sesuai dengan silabus. Bahan ajar yang digunakan merupakan sumber-sumber yang masih bersifat umum sehingga butuh waktu dalam mengkombinasikan setiap materi yang sesuai dengan silabus yang sudah ditetapkan. Ketika dosen dan mahasiswa ditawar dengan bahan ajar media pembelajaran matematika dan TIK yang utuh dalam satu buku, di terima dengan senang hati.

\section{Mengembangkan bahan ajar dengan MPI}

Mengidentifikasi kebutuhan instuksional dan menulis tujuan instuksional

\section{Mengidentifikasi kebutuhan intruksional}

Berdasarkan analisis kebutuhan mengambil keputusan bahwa perlu inovasi dari bahan ajar media pembelajaran matematika dan TIK. Inovasi ini didukung dengan hasil observasi didapat dalam menunjang pembelajaran sudah disedikan internet dengan menggunakan lab kompueter atau pun wife, proyektor, serta vasilitas lain yang dapat mendukung pembelajaran media pembelajaran matematika dan TIK. Selain itu mahasiswa dan dosen juga sudah update terhadap perkembangan IT, Sehingga analisis kebutuhan dan daya dukung sudah cukup apabila bahan ajar digunakan.

\section{Menulis Tujuan Instuksional}

Tujuan instruksional merupakan tujuan akhir yang dicapai mahasiswa setelah menggunakan bahan ajar media pembelajaran matematika dan TIK. Secara umum, tujuan instruksional adalah setelah mempelajari bahan ajar media pembelajaran matematika dan TIK diharapkan mahasiswa dapat mengaplikasikan teori dan mempraktek dalam bentuk produksi media dalam pembelajaran matematika

\section{Melakukan analisis pembelajaran}

Analisis instruktional merupakan penjabar dan tujuan instruksional yang telah ditetapkan menggunakan kata operasional sebagai berikut: 1). Menjelaskan Konsep media pembelajaran matematika , 2) Menjelaskan pemilihan media pembelajaran, 3) Menjelaskan alat peraga berbasis konsep luas) 4) Menjelaskan alat peraga berbasis konsep panjang,5) Menjelaskan alat peraga berbasis konsep volume, 6) Menjelaskan alat peraga berbasis geometri, 7) Menjelaskan pengembangan media pembelajaranT IK, 8) Menjelaskan pembuatan media audio visual, 9) Menjelaskan desain bahan ajar power Point, 10) Mengaplikasikan desaian bahan ajar Macromedia flash, 11) menjelaskan desaian bahan ajar blog.

\section{Mengidentifikasi perilaku dan karakteristik awal peserta didik}

\section{Perilaku peserta didik/Mahasiswa}

Populasi sasaran dilakukam pada: a) mahasiswa semester 4 yang mengkontrak mata kulaih media pembelajaran matematika dan TIK, b) Mata kuliah ini di ikuti program studi pendidikan matematika semeter 4 yang mempunyai minat untuk belajar matematika

\section{Karakteristik Awal Peserta didik/Mahasiswa}

Karakteristik mahasiswa yang akan di menggunakan bahan ajar memiliki latar belakang yang pendidikan heterogen, adalah yang dari SMK, SMA, dan MA. Mahasiswa yang mengikuti mata kuliah ini yang mempunyai keinginan yang tinggi untuk mempelajari media pembelajaran matematika dan TIK, serta sudah menguasai penggunaan alat teknologi komunikasi

\section{Menulis Tujuan Intruksional Khusus (TIK)}

Dari hasil analisis maka tujuan yang diharapkan adalah dapat: 1). Menjelaskan Konsep media pembelajaran matematika, 2) Menjelaskan pemilihan media pembelajaran, 3) Menjelaskan alat peraga berbasis konsep luas) 4) Menjelaskan alat peraga berbasis konsep panjang,5) Menjelaskan alat peraga berbasis konsep volume, 6) Menjelaskan alat peraga berbasis geometri, 7) Menjelaskan pengembangan media pembelajaranT IK, 8) Menjelaskan pembuatan media audio visual, 9) Menjelaskan desain bahan ajar power Point, 10) Mengaplikasikan desaian bahan ajar Macromedia flash, 11) menjelaskan desaian bahan ajar blog.

\section{Menyusun alat penilaian hasil belajar}

Tes penilaian hasil belajar dilakuakn untuk melihat pencapaian tujuan yang di tetapkan sesuai dengan prilaku pada tujuan instuksional khusus. Proses penilaian diambil dari partisipasi dalam pembelajaran, ujian mid semester, tugas, dan ujian akhir semester 


\section{Menyusun strategi pembelajaran}

Penyusun strategi pembelajaran merupakan tahapan-tahapan pada pendahuluan yang berisikan penjelasan. Pada tahap penyajian ada uraian materi, contoh, tes formatif,. Kemudian pada tahap penutup yang dilakukan adalah simpulan, unpan balik, dan tindak lanjut.

\section{Mengembangkan bahan instruksional}

Media pembelajaran matematika dan TIK disusun dengan memasukan materi yang relavan dengan perkembangan zaman. Bahan ajar terdiri dar sebalas bab yang kemas dalam bentuk e-book

\section{Menyusun desain dan melaksanakan evaluasi formatif \\ 1. Validasi Ahli}

a. Ahli Desain Pembelajaran

1) Penilaian ahli desain

Hasil penilaian ahli desain terhadap indikatorindikator yang di nilai, deskripsikan dalam bentuk gambar 2 .

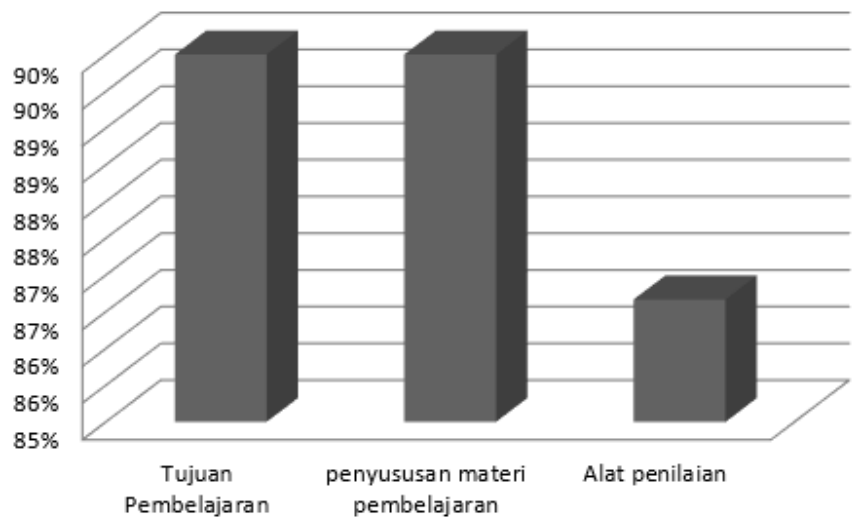

Gambar 2. Hasil Penilaian Ahli Desain Pembelajaran

Dari grafik terlihat bahwa nilai dari setiap aspek dari ahli desain adalah Aspek tujuan pembelajaran memperoleh nilai rata-rata 4,5 (90\%) aspek penyusunan materi 4,5 (90\%) dan alat penilaian $4,3(87 \%)$.

2) Revisi dan saran ahli desain

Ahli desaian pembelajaran memberikan beberapa saran perbaikan dan yaitu: saran dari evaluasi ahli desain adalah pada kejelasan perilaku audien perlu perbaikan kemudian kemudian kalimat perlu penegasan pada tujuan pembelajaran. Kemudian gunakan susun kalimat dalam bentuk eyd.Evaluasi formatif pada validasi one-to-one expert di bidang desain, sudah di revisi dan sudah diperiksa oleh ahli. Ahli merekomendasikan untuk evaluasi satu-satu pada pemakai.

\section{b. Ahli Media}

1) Validasi ahli media
Penilaian dari ahli media terhadap bahan ajar mata kuliah media pembelajaran matematika dan TIK dituangkan dalam bentuk Gambar 3.

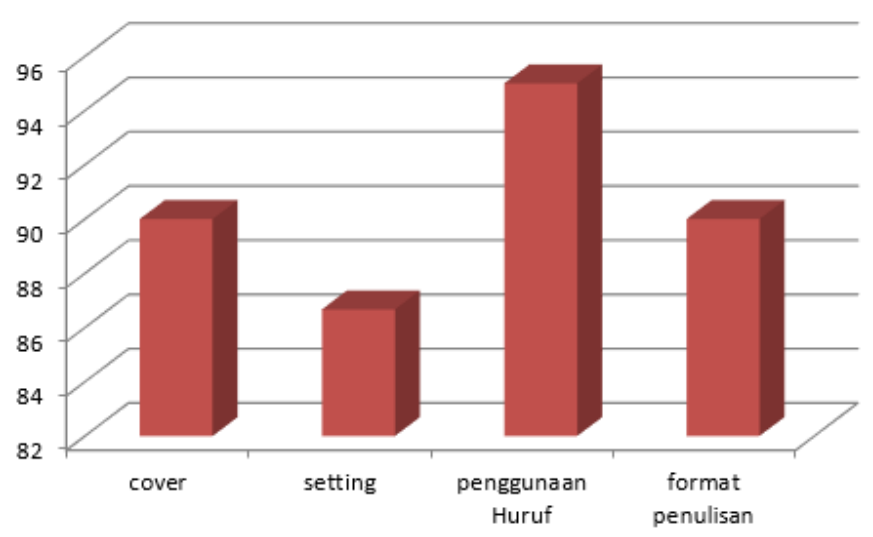

Gambar 3. Penilain validasi ahli media

Ahli media menilaian terhadap beberapa aspek yaitu aspek cover nilaia 4,5 (90\%), aspek sItting dengan nilai $4,43(86,7 \%)$, aspek penggunaan huruf dengan nilai $4,75(95 \%)$ dan aspek format penulisan 4,5 (90\%)

2) Revisi dan saran ahli media

Ahli media memberikan saran yaitu : pilih warna pada cover yang lebih menarik, halaman cover depan dan belakang sebaiknya senada, penulisan lebih konsisten. Evaluasi formatif one-to-one expert di bidang media telah diperbaiki dan direkomendasikan untuk melakukan evaluasi satu-satu

\section{c. Ahli Materi}

1) Penilaian ahli materi

Penilaian ahli terhadap bahan ajar media pembelajaran matematika dan TIK disajikan dalam gambar 4.

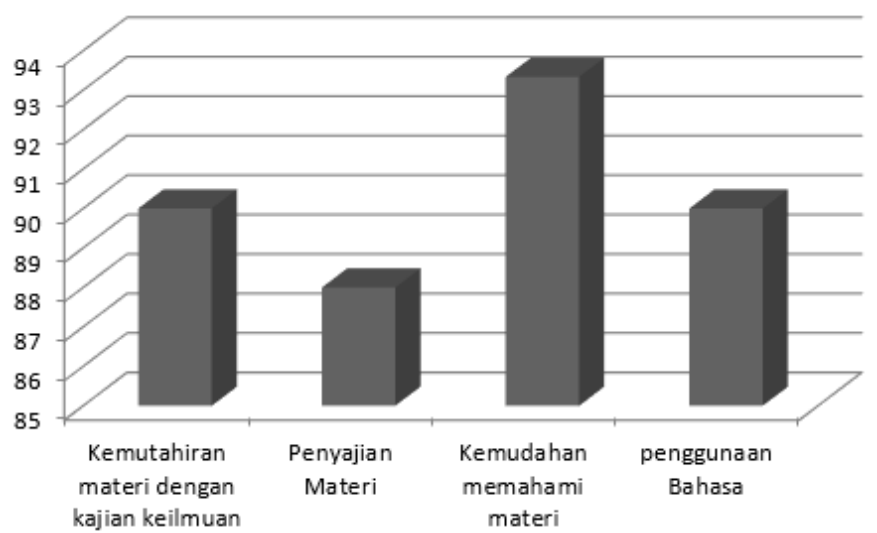

Gambar 4. Grafik Hasil Validasi Ahli materi

Ahli materi nilaia pada: aspek kemutahir materi dengan kajian keilmuan dengan nilai 4,5 (90\%0, asoek penyajian materi dengan nilai 4,4 (88), aspek kemudahan memahami materi dengan nilai 4,67 (93,3\%) dan aspek penggunaan bahasa dengan nilai 4,5 (90\%) 
2) Revisi dan saran ahli ateri

Saran perbaikan yaitu ada kesalahan dalam pengetikan. Saran dari ahli materi sudah diperbaikan dan ahli merekomendasikan untuk melakukan Evaluasi Satu-Satu

\section{Evaluasi satu-satu}

Evaluasi pada kelompok satu-satu untuk peserta didik di sajikan gambar 5 .

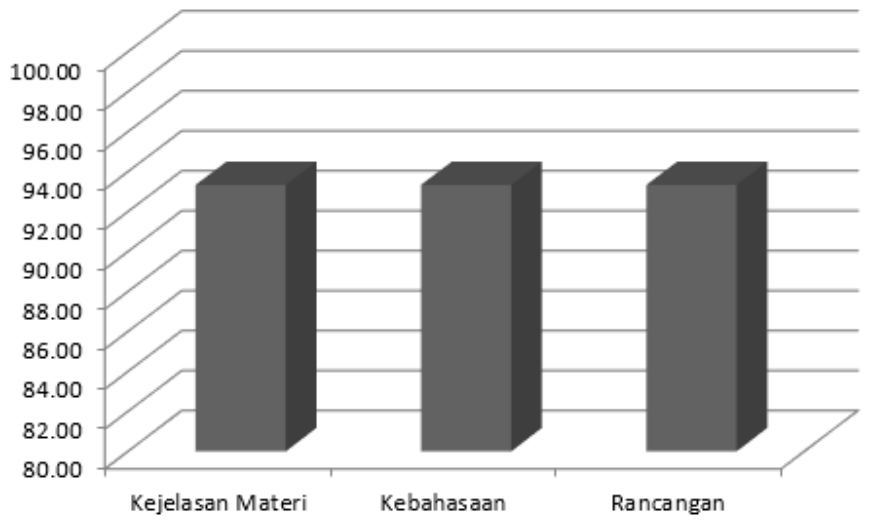

Gambar 5. Uji coba satu-satu.

Penialian pada aspek kejelasan materi memperoleh nilai 4,67 (93,3\%), aspek, aspek kebahasan dengan nilai 4,7 (93\%) dan aspek rancangan dengan nilai 4,67 $(93,3 \%)$. Tanggapan atau komentar dari evaluasi satu-satu adalah ada bahasa yang masih bersifat kata ilmiah agak sulit dipahami sehingga perlu disederhanakan bahasa pada kata tersebut, judul bab dab sub bab agar hurufnya lebih besar atau di bold agar lebih jelas

\section{Evaluasi kelompok kecil (small group)}

Evaluasi Uji coba kelompok kecil pada gambar 6:

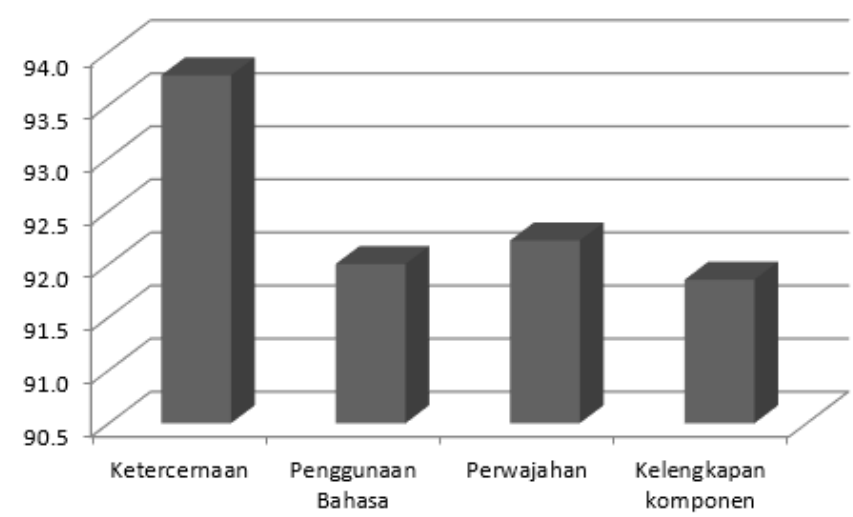

Gambar 6. Hasil uji coba kelompok kecil

Penilaian evaluasi satu-satu terhadap aspek ketercernaan memperoleh nilai 4,67 $(93,8 \%)$, aspek penggunaan bahasa dengan 4,6 (92\%), aspek perwajahan 4,61 (92.2\%), dan aspek kelengkapan komponen 4,59 (92,9\%). Berdasarkan hasil yang diperoleh menujjukan bahwa kelompok besar

\section{Uji coba kelompok lapangan (field trial)}

Hasil penilaian uji lapangan di deskripsikan gambar 7:

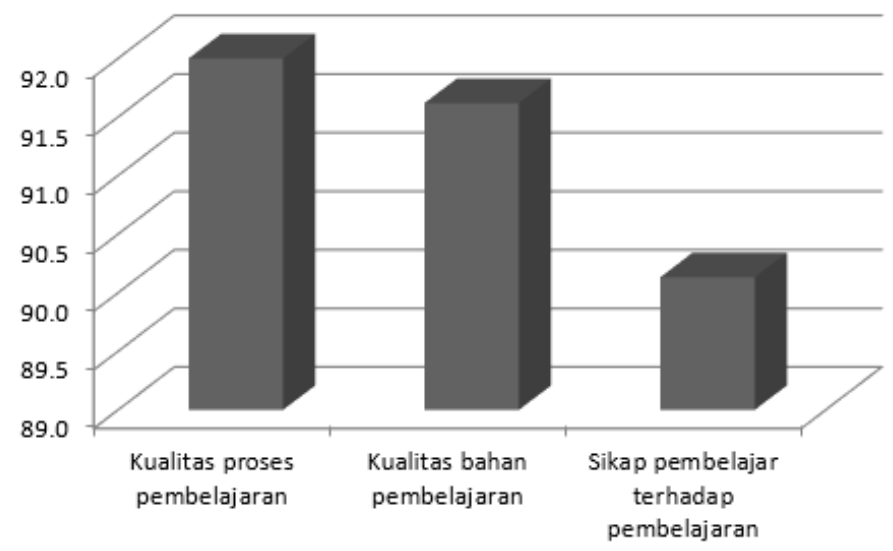

Gambar 7. Hasil uji coba lapangan

Pada uji coba lapangan terdapat tiga aspek yaitu aspek kualitas proses pembelajaran dengan nilai 4,6 (92\%), aspek kualitas bahan pembelajaran dengan $4,58(91,62 \%)$ dan aspke sikap pembealajaran terhadap pembelajaran $4,51(90,1 \%)$.

Hasil penialian dari uji coba kelompok lapangan sudah tidak ada lagi dilihat dari pelaksanaan secara online atau daring, mahasiswa antusias mengikuti serta menggumpul tugas produksi media dengan baik.

\section{Pembahasan \\ Pentingnya pengembangan Bahan ajar media pembelajaran matematika dan TIK}

Proses inovasi pembelajaran pada perguruan tinggi merupakan tuntutan logis dari ilmu pendidikan dan teknologi yang terus berkembang. Perkembangan tersebut harus dapat menyesuaikan dengan peningkatan pembelajaran dan kualitas lulusan yang siap dipakai dalam dunia pendidikan khususnya sebagai guru matematika. Dengan demikian lulusan akan dapat dengan mudah menyesuaikan media pembelajaran di mana berada sesuai dengan lingkungan yang ada.

Kualiatas pembelajaran memang erat kaitan dengan rancangan pembelajaran yang disusun oleh pengajar/dosen. Dalam proses pembelajaran dosen dalam membuat merancang pembelaajran di awali dengan kesenjangan antara kondisi yang ada dengan kebutuhan yang diingikan. Ketika mendapat kesenjangan maka harus di cari pemencahan masalah yang sesuai untuk mengatasi kesenjangan tersebut. Kesenjangan yang ada di jadikan informasi di dalam pengembangan sebuah produk.

Hasil penelitian pendahuluan menunjukkan kesenjangan antara proses pembelajaran terdahulu dengan proses pembelajaran khusus dalam penggunaan bahan ajar yang terjadi saat ini dalam mencapai suatu tujuan pembelajaran yang diingikan. Analisis kebutuhan menunjukkan bahwa para lulusan menyatakan bahwa 
ada beberapa materi yang didapat di perguruan tinggi kurang sesuai dengan keaadaan dilapangan, karena materinya masih bersifat umum. Selain itu, bahan ajar yang khusus untuk media pembelajaran matematika belum ada dan hanya menggunakan bahan ajar media yang bersifat umum. Kesenjangan tersebut ditindak lanjuti dengan melakukan pengembangan bahan ajar media pembelajaran dan TIK. Mengingat pentingnya pengembangan bahan ajar media pembelajaran matematika dan TIK seperti uraian di atas, maka sudah tepat untuk dijadikan acuan dalam mengembangkan bahan ajar.

\section{Prosedural pengembangan Bahan ajar media pembelajaran matematika dan TIK}

Upaya dalam mendapat hasil bahan ajar yang optimal memerlukan kreativitas dosen dalam mendesain pembelajaran. Prosedur mengembangan bahan ajar media pembelajaran matematika dan TIK mengacu pada tahapan-tahapan model pengembangan instruksional (MPI). Setiap tahapan pada Model ini memiliki rincian yang je dari jelas dari awal hingga akhir. Salah satu langkah yang penting adalah mengidentifikasi kebutuhan instuksional dan menulis tujuan instruksional. Suatu desaian pembelajaran harus mengkaji analisis kebutuhan dan menetapkan tujuan pembelajaran yang diinginkan. Tujuan pembelajaran merupakan kemampuan atau keterampilan (kompetensi) yang diharapkan dapat dimiliki oleh mahaiswa setelah melakukan proses pembelajaran tertentu (Sanjaya, 2008). Dimana kompentensi merupakan kemampuan mahasiswa untuk mengerjakan sesuatu dengan baik sebagai hasil dari proses pembelajaran atau pendidikan yang diikutinya (Bermawi, 2009)

Untuk mecapai tujuan pembelajaran yang ditetapkan maka dilanjutkan dengan melakukan analisis intruksional. langkah analisis instruktional, yaitu mengidentifikasi kompetensi umum menjadi sub kompentensi yang disusun secara sistematis. Hasil analisis intruksional adalah peta kompentensi yang menunjukkan sub-sub kompetensi dari awal hingga akhir. Dengan demikian akan mudah mencapai tujuan instruksional yang ditetapkan.

Langkah selanjutnya adalah analisis terhadap perilaku dan karakteristik mahasiswa. Analisis konteks merupakan suatu yang berhubungan dengan keterampilan yang akan dipelajari. Bahan ajar yang dihasilkan akan diperuntukkan bagi mahasiswa prodi pendidikan matematika. Karakteristik mahasiswa adalah individu-individu yang dapat mengarahkan dirinya sendiri. Karakteristik ini menunjukan bahwa mahasiwa dalam usia dewasa yang mencakup pada kompetensi intelenggensi, kreativitas, motivasi dan mental yang kuat.dari aspek intelegensi mahasiswa sudah dapat berpikir secara logis, menngukapkan ide, dan pemecahan masalah.
Setelah itu melakukan analisis tujuan istruksional khusus untuk menyusun alat penilaian hasil belajar, men desain strategi dan sebagai pedoman dalam mendesaian bahanbahan ajar.. Setelah dikembangkan maka di lanjutkan dengan evaluasi formatif kepada ahli materi, media, dan ahli desian.

Hasil evaluasi oleh ahli (materi, desain, materi), evaluasi satu-satu, evaluasi kelompok kecil dan uji coba lapangan menunjukkan bahwa pengembangan bahan ajar media pembelajaran matematika dan TIK sudah mampu memberikan nilai tambah dalam meningkatkan komptensi mahasiswa dan efektif dalam mengembangkan kreatifitas mahasiswa.hal tersebut dibukti dengan hasil produksi media yang dihasilkan oleh mahasiswa.

\section{Faktor pendukung dan penghambat}

Faktor pendukung dalam pengembang bahan ajar diantaranya adalah: 1). Dosen, Dosen yang mengampu mata kuliah merupakan dosen menguasai materi dan pemanfaatan sarana dan prasana yang ada. Salah satu contoh adalah Ketika produk ini di ujicoba pada keadaan pandemic virus covid 19 yang menjadi bencana nasional, sehingga pembelajaran dilakukan secara daring atau online. 2). Mahasiswa, Selama pembelajaran yang dilakukan berlangsung secara online karena pandemic virus covid 19, sehingga menuntut mahasiswa lebih banyak belajar secara mandiri. Kemandirian dalam belajar akan membentuk kepercayaaan diri yang kuat dalam melakukan tugas yang diberikan. Hasil dari pembelajaran menunjukkan bahwa mahasiswa benarbenar mampu melakukan dengan baik. 3). Sarana dan prasarana, Saran dan prasana mendukung pembelajaran penbelajaran secara online karena mahasiwa dan dosen sudah memiliki sarana dan prasana untuk pembelajaran online.

Kemudian Factor penghambat dalam pengembangan bahan ajar media pembelajaran matematika adalah : 1) ujii coba produk dilakukan pada saat pandemic virus covid 19, sehingga pembelajaran dilakukan secara daring atau online. Hal ini merupakan penghambat ketika mengobservasi secara langsung proses pembelajaran yang dilakukan. Sehingga tidak dapat diamti secara menyeluruh proses pembelajaran yang dilakukan. 2) Kesiapan dosen dan mahasiswa dalam pembelajaran online atau daring. Dosen dan mahasiwa harus mempersiapkan diri secara baik dalam pembelajaran yang dilakukan, karena pembelajaran secara online secara meyeluruh untuk semua pertemuan baru sekali ini dilakukan. 3) Kendali lain adalah waktu, karena pembelajaran dilakukan secara daring atau online membuat diskusi dan tanya jawab sering melebihi waktu yang ditentukan. 4) Sarana dan prasarana. Pembelajaran dilakukan secara online sehingga sarana dan prasaran yang digunakan adalah milik dosesn dan mahasiswa mulai hari perangkat seperti laptop maupun HP serta 
kuata internet. Keadaan online juga menyebabkan sering koneksi terputus karena kehilangan sinyal.

\section{SIMPULAN}

1. Pelaksanaan pembelajaran mata kuliah media pembelajaran matematika dan TIK, mengunakan bahan ajar yang bersifat umum dengan materi yang terpisah-pisah dan belum sesuai dengan susunan silabus. Mahasiwa sering mendapat kesulitan ketika menerapkan teori ke praktek pembuatan media yang sesuai dengan materi matematika. Hal tersebut dikarena matematika memiliki karakteristik yang abstrak. Oleh sebab itu dibutuh suatu bahan ajar khusus untuk media pembelajaran matematika

2. Proses mendesain dan mengembangkan bahan ajar media pembelajaran matematika dan TIK menggunakan model MPI dalam bentuk buku. Bahan ajar yang berbentuk tersebut dikembangkan sudah melalui evaluasi formatif yang dilakukan kepada beberapa ahli/pakar dan telah dilakukan perbaikan. kemudian di lanjutkan dengan evaluasi satu-satu, evaluasi kelompok kecil, dan uji coba lapangan. Hasil formatif memperoleh hasil yang bagus sehingga bahan ajar media pembelajaran matematika dan TIK layak digunakan..

\section{DAFTAR PUSTAKA}

Arsyad, A., 2014. Media Pembelajaran. Jakarta: PT Rajagrafindo Persada

Asyhar, R., 2012. Kreatif Mengembangakan Media Pembelajaran. Jakarta: Referensi

Awalludin. 2017. Pengembangan Buku Teks Sintaksis Bahasa Indonesia. Yogyakarta: Deepublish.

Bermawi Munthe. 2009. desain pembelajaran. Yokyakarta: Pustka insan Madani

Buyung, 2018. Pengembangan Bahan Ajar Pada Mata Kuliah Belajar Dan Pembelajaran Di Fakultas Keguruan Dan Ilmu Pendidikan Universitas Batanghari Jambi http://ji.unbari.ac.id/index.php/ilmiah/article/view/ 517

Depdiknas. 2008. Panduan Pengembangan Bahan Ajar. Jakarta: Depdiknas

Hamdani. 2011. Strategi Belajar Mengajar, Bandung: CV. Pustaka Setia

https://bpptik.kominfo.go.id/glosarium/teknologiinformasi-dan-komunikasi/ (diakses 9 Februari $\underline{2020)}$

M. Atwi Suparman. 2011, Desain Instruksional , Jakarta: Universitas Terbuka

M. Atwi Suparman. 2012. Desain instruksional modern, Jakarta: Erlangga

Richey, C. Rita, Klein, D. James. 2007. Design and Development Research. New Jersey: Lawrence Lrlbaum Associates.

Wina sanjaya. 2008 Kurikulum dan pembelajaran. Jakarta: Kencana prenada media group 